\title{
Erosion Corrosion Study of HVOF Sprayed Thermal Sprayed Coatings on Boiler Tubes: A Review
}

\author{
Rakesh Kumar $^{\mathrm{a}}$, Rajesh Kumar ${ }^{\mathrm{b}}$, Santosh Kumar ${ }^{\mathrm{c}, \mathrm{d}}$ \\ a,b) Department of Mechanical Engineering, CGC-Chandigarh Engineering College, Landran, Mohali, Punjab, India. \\ c) Research Scholar, Department of Mechanical Engineering, IKG Punjab Technical University, Kapurthala, Punjab, India. \\ d) Department of Mechanical Engineering, CGC-College of Engineering, Landran, Mohali, Punjab, India.
}

\begin{abstract}
Many industrial parts used in power generation industries fail due to erosion, corrosion, and abrasion causes huge economic losses. These problems can be overcome by either changing the material or changing the environment or by separating the material surface from the corrosive environment. The distinct investigations have been carried out to overcome the erosion problems and observed that erosion resistant coatings have been gaining more importance in recent times. Among the different thermal spray coating techniques, High Velocity Oxy Fuel (HVOF) has emerged as an effective, advanced and rapidly developing process to produce dense coating at relatively low temp. with low porosity (less than 1\%). HVOF has been widely adopted by many industries due to its several advantages such as high micro-hardness, adhesion strength, and erosion-corrosion and wear resistance, flexibility, and cost effectiveness with homogenous coating. The main purpose of this review paper is to review previous research in the field of high velocity Oxy-fuel (HVOF) sprayed coating, especially in context with Indian boiler tubes. In addition, an attempt has been made to study their basic principles, merits, demerits, applications and comparison.
\end{abstract}

Key words - High Velocity Oxy Fuel (HVOF), Boiler, Erosion and Corrosion.

\section{INTRODUCTION}

High temperature corrosion commonly known as hot corrosion is a severe problem in boiler tubes, fluidized bed combustion devices, gas turbines, I.C. engines, and industrial waste incinerators etc. [1]. Erosion corrosion (E-C) alone has been reported to be responsible 50-75\% of total arrest time in such devices and account for the multimillion dollar loss to the relevant industries [2]. In Indian coal fired boiler low grade coal is used as a fuel, which contains sulphur contents [3]. During combustion it produces $\mathrm{SO}_{2}$, which is partly oxidized to Sulfur trioxide $\left(\mathrm{SO}_{3}\right)$. This $\mathrm{SO}_{3}$ further reacts with sodium chloride $(\mathrm{NaCl})$ and water vapour to give $\mathrm{Na}_{2} \mathrm{SO}_{4}$ (melting point $884^{\circ} \mathrm{C}$ ), at combustion temperatures [4]. A small amount of vanadium (V) may also be present in coal, which on combustion forms Vanadium pentoxide $\left(\mathrm{V}_{2} \mathrm{O}_{5}\right)$ having melting point $670^{\circ} \mathrm{C}$. This may further react with Sodium sulfate $\left(\mathrm{Na}_{2} \mathrm{SO}_{4}\right)$ to form sodium vanadates $\left(\mathrm{Na}_{3} \mathrm{VO}\right)$ having a low melting point. These sodium vanadates $\left(\mathrm{Na}_{3} \mathrm{VO}\right)$ are extremely corrosive to high temperature materials such as metal and alloy used in the combustion system [5-6]. Overall economic loss due to all the types of corrosion in India, accounts to US\$ 6500 million annually [7]. So, it is essential to understand the nature of various types of metal and alloy degradation to avoid their premature failures which ensure reliability and safety [8].Thermal spray coating is a way of increasing the limits of use of materials for higher temperature applications like in boiler and gas turbine etc. [9] The coatings used at in such applications must be dense enough that any residual voids can be filled by formation of protective oxides and be thick enough to postpone the diffusion of corrosive species to the substrate material until protective oxides form within the coating [10]. There are many thermal spray techniques that can be used to deposit metallic coatings; however, thermal spray techniques such as flame spraying, arc spraying, plasma spraying, D-Gun, and HVOF spraying are extensively used for higher temperature application [11]. Among different thermal spraying techniques HVOF has emerged as an important sophisticated surface engineering tool to produce dense coatings with high micro hardness and adhesion values, and good erosion, 
corrosion, and wear resistance properties [12]. HVOF coatings are homogeneous and dense as compared to the other types of thermal-sprayed coatings; nevertheless some residual oxides and porosity remain at splat boundaries [13].This processes invented in the early 1980s by Browning and Witfield, while using rocket engine technologies. The process uses a combination of oxygen $\left(\mathrm{O}_{2}\right)$ with one of the fuel gases including hydrogen $\left(\mathrm{H}_{2}\right)$, propane $\left(\mathrm{C}_{3} \mathrm{H}_{8}\right)$, propylene $\left(\mathrm{C}_{3} \mathrm{H}_{6}\right)$, and even kerosene. Then the fuel $\left(\mathrm{C}_{3} \mathrm{H}_{6}\right)$ and oxygen $\left(\mathrm{O}_{2}\right)$ are compressed into a combustion element/chamber in a regular flow, producing a jet of combustion products at extreme velocity. Powder particles (Ni/ Ni-20Cr/Ni-5Al, etc) injected into this gas steam are swifted to a extreme velocity. Fusion is attained by the kinetic energy impact of the coating particles not by their elevated temperature: the HVOF process is done in an atmospheric environment. The flame temperature changes from $2500{ }^{\circ} \mathrm{C}$ to $3200{ }^{\circ} \mathrm{C}$, depending on the fuel, the fuel gas/ oxygen ratio and the gas pressure [14]

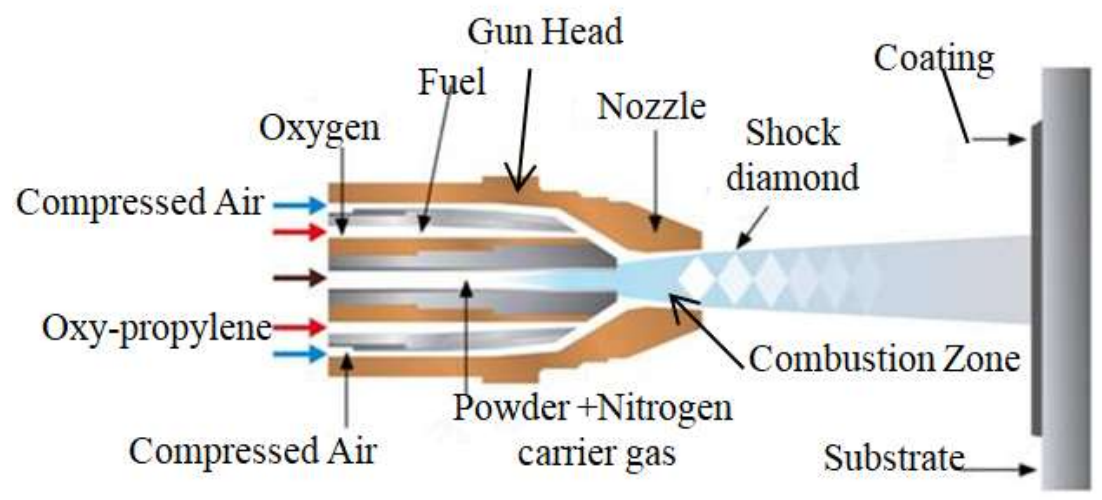

Fig. 2.21 Schematic diagram of the HVOF process [15].

\section{A) Merits \& Demerits:}

The main advantages of this process is lower porosity $(<1 \%)$ because of higher particle impact velocities, higher bond strength $(>80 \mathrm{Mpa})$, smoother spray surface due to more impact velocities and smaller powder sizes, higher wear resistance because of tougher, harder coatings upto $1400 \mathrm{Hv}$, dense, and thick coating due to less residual stresses [16-18]. In addition HVOF have reduces downtime, quick to apply, low environmental impact compared to electroplating processes, and improved density and less cracks and pores [19].

The main disadvantages of HVOF spraying include: It can be more complex, with their properties and microstructure depending upon several processing variables, powder sizes is restricted to a range of about 5 $60 \mu \mathrm{m}$, with a need for narrow size distributions. In addition it is costly and requires qualified personnel to ensure safe operation, and to achieve consistent coating quality. Deposition of coatings is difficult or impossible to achieve on to internal surfaces of small cylindrical components, or other restricted access surfaces, because HVOF spraying needs line of sight to the surface and a spray distance of 150-300 mm.

\section{B) Applications:}

The HVOF sprayed coatings have found wide application in marine, oil and gas, paper, petrochemicals, aircraft, automotive, power, mining, chemical, and other industries. For reclaiming a wide range of petrochemicalprocess components such as storage vessels, heat exchangers, pipe end fittings and valves, which are subjected to severe erosive, wear and corrosive conditions, Amoco Oil Company routinely employs the HVOF process by applying AISI 316 L and Hastalloy C-276 coatings [20]. The HVOF thermal spraying process has also been successfully employed to repair stainless steel and D2 tool steel substrate with different depth of damage to a built-up thickness of up to $5.5 \mathrm{~mm}$. Sprayed material had good adherence to the substrate under various types of aggressive machining processes [21]. It is a relatively cool process which leads to minimal distortion or 
metallurgical change to the sprayed material. In addition the HVOF Coating most commonly used as a replacement for environmentally damaging Hard Chrome, Pumps, Seals, Valves, wire drawing equipment, hard chrome replacement, Actuators, Impellers, Rams, Pistons, Bearings, Shafts, Wear and corrosion protection, Wear Rings, valve plugs and Drilling Tools. HVOF is extensively applicable for high-quality production, wearresistant coating of satellites and carbides [22].

c) Comparison of Thermal Spray Process.

Table 1. Comparison of characteristics for various thermal spraying processes [23]

\begin{tabular}{|c|c|c|c|c|c|c|c|c|}
\hline S.No & Process & Heat source & Propellant & $\begin{array}{l}\text { Material } \\
\text { feed type }\end{array}$ & $\begin{array}{l}\text { Spray } \\
\text { gun } \\
\text { temp. } \\
\left({ }^{\circ} \mathrm{C}\right)\end{array}$ & $\begin{array}{c}\text { Particle } \\
\text { velocity } \\
(\mathbf{m} / \mathbf{s})\end{array}$ & $\begin{array}{c}\text { Coating } \\
\text { materials }\end{array}$ & $\begin{array}{c}\text { Porosity } \\
\text { level } \\
\text { vol. \% }\end{array}$ \\
\hline 1 & $\begin{array}{l}\text { Electric } \\
\operatorname{arc}\end{array}$ & $\begin{array}{l}\text { Arc between } \\
\text { electrodes }\end{array}$ & Air & Wire & 6000 & 240 & $\begin{array}{c}\text { Ductile } \\
\text { materials }\end{array}$ & $8-15$ \\
\hline 2 & $\begin{array}{c}\text { Plasma } \\
\text { arc } \\
\text { spraying }\end{array}$ & Plasma arc & Air & Wire & 6000 & $120-600$ & $\begin{array}{l}\text { ceramic, } \\
\text { plastic, and } \\
\text { compounds }\end{array}$ & $2-5$ \\
\hline 3 & $\begin{array}{c}\text { Low } \\
\text { pressure } \\
\text { plasma } \\
\text { spraying }\end{array}$ & Plasma arc & Inert gas & Powder & 16000 & 500 & $\begin{array}{c}\text { Metallic, } \\
\text { ceramic, } \\
\text { plastic, and } \\
\text { compound }\end{array}$ & $<5$ \\
\hline 4 & $\begin{array}{c}\text { Flame } \\
\text { spraying }\end{array}$ & $\begin{array}{c}\text { Oxy- } \\
\text { acetylene/ } \\
\text { oxy-hydro gen }\end{array}$ & Air & Powder & 3000 & $30-120$ & $\begin{array}{c}\text { Metallic and } \\
\text { ceramics }\end{array}$ & $10-20$ \\
\hline 5 & D-Gun & $\begin{array}{l}\text { Oxygen } \\
\text { acetylene }\end{array}$ & $\begin{array}{c}\text { Detonation } \\
\text { shock } \\
\text { waves }\end{array}$ & Powder & 4500 & 800 & $\begin{array}{c}\text { Metallic, } \\
\text { ceramic, } \\
\text { plastic, and } \\
\text { compounds }\end{array}$ & $0.1-1$ \\
\hline 6 & HVOF & $\begin{array}{c}\text { Oxypropy } \\
\text { lene/ } \\
\text { hydrogen/ } \\
\text { propane/ LPG }\end{array}$ & $\begin{array}{c}\text { Combustion } \\
\text { jet }\end{array}$ & $\begin{array}{c}\text { Powder/ } \\
\text { wire }\end{array}$ & 3000 & 800 & $\begin{array}{l}\text { Metallic and } \\
\text { ceramic }\end{array}$ & $0.1-2$ \\
\hline
\end{tabular}

\section{LITERATURE REVIEW}

In this section studies by various researchers in simulated and actual boiler environment are presented.

T.S. Sidhu et al. [24] successfully deposited NiCrBSi coating on SN 600, SN 601, and SF 800H steel in simulated boiler environment at $900^{\circ} \mathrm{C}$ using $\mathrm{HVOF}$ process. The author found that $\mathrm{NiCrBSi}$ coating on $\mathrm{SF}$ $800 \mathrm{H}$ reduce maximum hot corrosion $80 \%$, while NiCrBSi coating on SN 600 and SN 601 steel reduce hot corrosion by $40 \%$ and $65 \%$ respectively. H.S. Sidhu et al. [25] studied the hot corrosion behaviour of $\mathrm{Cr} 3 \mathrm{C} 2$ $\mathrm{NiCr}, \mathrm{NiCr}, \mathrm{WCC}$, and Stellite -6 coating on T11 boiler tube steel at $900^{\circ}$ under simulated environment. From the experimental results it was observed that the aforementioned coating reduced hot corrosion $89 \%, 94 \%, 40$ and 53\% respectively. The bare steel GrA1 shows poor result of hot corrosion as compared to coated steel. T.S. Sidhu et al. [26] investigated hot corrosion performance of NiCrBSi, and Stellite-6 coating on SN 600 substrate at extreme temperature in boiler environment. The NiCrBSi, and Stellite-6 coating were found to be less useful as it reduce hot corrosion by $37 \%$ and $21 \%$ respectively. Many authors [27-30] deposited HVOF sprayed, WC- 
Co, satellite-6, Ni, Cr, and Fe, based coating on boiler steels (347H, T91, T22, SN 601, SN 75 and SN 718) at $900^{\circ} \mathrm{C}$. From the result it is observed that $\mathrm{Cr} 3 \mathrm{C} 2-25(\mathrm{Ni} 20 \mathrm{Cr}$ ) coating on $\mathrm{T} 91$ decrease maximum hot corrosion (80\%). H.S. Sidhu et al. [31] successfully deposited NiCr coatings on GrA1, T-11, and T-22 boiler steels by LPG (liquefied petroleum gas) assisted HVOF spray process. The kinetics of corrosion was studied using thermogravimetric at $900^{\circ} \mathrm{C}$ in the molten salt atmosphere. From the experiments result of SEM/EDAX, XRD and EPMA techniques, the NiCr coating on GrA1, T-11, and T-22 steel reduce hot corrosion in the order of $96.97,94.13$, and $95.26 \%$ respectively. This may be due to the formation of protective oxide such as $\mathrm{NiO}, \mathrm{Cr}_{2} \mathrm{O}_{3}$ and $\mathrm{NiCr}_{2} \mathrm{O}_{4}$. The porosity, thickness, and average microhardness of the $\mathrm{NiCr}$ coating were found to be less than $1 \%, 300 \mu \mathrm{m}$, and $400 \mathrm{Hv}$ respectively. The bare steels specimen shows $\mathrm{Fe}_{2} \mathrm{O}_{3}$ as the main ingredient of scale. Whereas coated samples indicate the presence of $\mathrm{Fe}_{2} \mathrm{O}_{3}, \mathrm{Cr}_{2} \mathrm{O}_{3}, \mathrm{NiO}$ and $\mathrm{NiCr}_{2} \mathrm{O}_{4}$ phases in the scales. The uncoated boiler tube steels samples showed peeling of scale, intense spalling, cracking and enormous weight gain during hot corrosion studies in $\mathrm{Na}_{2} \mathrm{SO}_{4}-60 \% \mathrm{~V}_{2} \mathrm{O}_{5}$ at $900^{\circ} \mathrm{C}$. Whereas coated selected specimen showed more hot corrosion resistance. T S Sidhu, S Parkash and R D Aggerwal et al [32] investigated the hot corrosion behavior of a Ni-based super alloy $(19.5 \mathrm{Cr}-3 \mathrm{Fe}-0.3 \mathrm{Ti}-0.1 \mathrm{C}$-balance $\mathrm{Ni}$ ) coated by $\mathrm{Cr} 3 \mathrm{C} 2-\mathrm{NiCr}$, NiCrBSi, Stellite-6 and Ni-20Cr powders using an HVOF process. From the investigation it was found that $\mathrm{Ni}-20 \mathrm{Cr}$ shows better result of hot corrosion as compared with satellite- 6 coating. M Kaur, H Singh, and S. Prakash et al. [33] successfully deposited $\mathrm{Cr}_{3} \mathrm{C}_{2}$-NiCr coating on $\mathrm{SAE}-347 \mathrm{H}$ boiler steel by High velocity oxy fuel process. The base steel SAE-347H shows poor result of hot corrosion $(6.17 \mathrm{mg} / \mathrm{cm} 2)$ as compared to coated steel $\left(2.925 \mathrm{mg} / \mathrm{cm}^{2}\right)$. Rakesh Bhatia, H. S. Sidhu, B. S. Sidhu et al. [34] Studied the usefulness T91 boiler tube steel coated by $75 \% \mathrm{Cr} 3 \mathrm{C} 2-25 \%$ (Ni-20Cr) coating powders by HVOF technique to control hot corrosion at various temperatures i.e. 550,700. The bare steel T91 indicates poor result of hot corrosion as compared to coated steel at all operating temperatures. Singh et. al. studied that to prevent from corrosion T91 boiler tube steel, the coatings of powder $\mathrm{Cr} 3 \mathrm{C} 2-25$ ( $\mathrm{Ni}-20 \mathrm{Cr}$ ) and $\mathrm{Ni}-20 \mathrm{Cr}$ were deposited by high velocity oxy-fuel (HVOF) process. The bare and coated T-91 steel samples were tested for hot corrosion studies in molten salt $\left(\mathrm{Na}_{2} \mathrm{SO}_{4}-\right.$ $60 \% \mathrm{~V}_{2} \mathrm{O}_{5}$ ) environment at $900^{\circ} \mathrm{C}$ temperature under cyclic conditions and each cycle consisted $1 \mathrm{~h}$ of heating in tube furnace followed by $20 \mathrm{~min}$ in air cooling. Using thermo gravimetric technique, the weight change measurements were tested after each cycle in order to establish the kinetics of corrosion. To analyze the corrosion products, $\mathrm{x}$-ray diffraction and scanning electron microscopy/energy dispersive $\mathrm{x}$-ray analysis were used. The uncoated steel has higher weight gain during testing due to the formation of un-protective $\mathrm{Fe} 2 \mathrm{O} 3$ dominated oxide scales. The $\mathrm{Cr} 3 \mathrm{C} 2-25(\mathrm{Ni}-20 \mathrm{Cr})$ coating was found more protective and have better results than the $\mathrm{Ni}-20 \mathrm{Cr}$ coating [35]. Chatha et. al. investigate that $75 \mathrm{Cr} 3 \mathrm{C} 2-25 \mathrm{NiCr}$ coating can be deposited by high velocity oxy-fuel (HVOF) process on T91 boiler tube steel substrate to enhance high-temperature/hot corrosion resistance. In the present investigation high-temperature corrosion behavior of bare as well as coated steels were evaluated. For this investigation, the experiments were conducted at $900^{\circ} \mathrm{C}$ for 15 cycles each of $100 \mathrm{~h}$ duration and $1 \mathrm{~h}$ cooling at ambient temp. The investigation of the bare and coated steel specimens were done with the help of metal thickness loss and corresponding to the corrosion scale formation and also with the depth of internal corrosion attacks. The bare boiler tube steel suffered from a catastrophic degradation in the form of internal oxidation attack and thickness loss. The $75 \mathrm{Cr} \mathrm{C}-25 \mathrm{NiCr}$ coating shows good result as compare to bare steel and also no tendency for internal oxidation [36]. From the literature it has been concluded that although the work has been done in the field of erosion and corrosion testing of thermal spray coated steels, but more research is needed to evaluate the performance of these coatings in more aggressive environments, whether in the laboratory conditions or in actual boiler conditions. More work is needed to understand the combined effect of erosion- corrosion (E-C) of HVOF sprayed of different coatings on different materials.

\section{CONCLUSION}

It has been concluded from the results of various researchers that HVOF process have gaining high potential due to increased thickness capability $(200-300 \mu \mathrm{m})$, higher micro hardness, less porosity usually < $1 \%$, dense coating and good adhesion strength. Further, it has been concluded that Ni-Cr based coatings offered very high hot corrosion resistance. In addition HVOF process is widely used for commercial applications, since 
it provides well bonded, wear resistant and corrosion resistant coatings, Moreover, the application of HVOF coating to the operating components will increase working life of these components.

\section{REFERENCES}

[1] A.S. Khanna and S.K. Jha, "Degradation of Materials under Hot Corrosion”, Trans., Indian Inst. Met., Vol. 51(5), pp. 279-290, 1998.

[2] R. Kumar, R. Singh, and S. Kumar, "Erosion and Hot Corrosion Phenomena in Thermal Power Plant and their Preventive Methods: A Study,"Asian Review of Mechanical Engineering, Vol. 7 (1), pp 38-45, 2018.

[3] S. Srikanth, S., B. R. kumar, S.K., Das, K..Gopalakrishna, K.. Nandakumar, and P. Vijayan, “Analysis of Failures in Boiler Tubes due to Fireside Corrosion in a Waste Heat Recovery Boiler,” Engg. Failure Analysis, Vol.10, pp.59-66, 2003.

[4] K. Natesan, "Corrosion-Erosion Behavior of Materials in a Coal-Gasification Environment," Vol.21, pp. 364-370, 1976.

[5] Y.S. Hwang, and R.A. Rapp.,"Thermo-Chemistry and Solubility of Oxides in Sodium Sulfate-Vanadate Solutions," Corros, Vol. 11, pp.933-937, 1989.

[6] A.S. Khanna, and K.S. Jha, K.S., "Degradation of Materials under Hot Corrosion Conditions," Trans. Indian Inst. Met., Vol.5, pp. 279$290,1998$.

[7] S. Kumar, M. Kumar, A. Handa, “Combating Hot Corrosion of Boiler Tubes-A Study,” Engineering Failure Analysis, Vol. 94, pp. 379-395, 2018.

[8] B. S. Sidhu and S. Parkash, "High-Temperature Oxidation Behavior of NiCrAlY Bond Coats and Stellite-6 Plasma Sprayed Coatings, Oxidation of Metals", Vol. 63, pp.45-49, 2005.

[9] W.M. Zhao, Y. Wang, L.X. Dong, K.Y. Wu, and J. Xue, “Corrosion Mechanism of NiCrBSi Coatings Deposited by HVOF,”Surf. Coat. Technol., Vol.190,pp 293-298, 2005.

[10] T.S. Sidhu, S. Prakash, and R.D. Agrawal, "Studies on the Properties of High-Velocity Oxy-Fuel Thermal Spray Coatings for Higher Temperature Applications,” Mater. Sci., 41(6), pp. 805-823, 2005.

[11] R. Kumar and S. Kumar, "Comparative Parabolic Rate Constant and Coating Properties of Nickel, Cobalt, Iron and Metal Oxide Based Coating: A Review,” I Manager's Journal of Material Science, Vol. 6(1), pp 45-56, 2018.

[12] R.Kumar and S.Kumar, "Thermal Spray Coating: A Study, IJESRT, Vol.7 (3), pp 610-617, 2018.

[13] M.A. Uusitalo, P.M.J. Vuoristo, and T.A. Mantyla, "High Temperature Corrosion of Coatings and Boiler Steels in Reducing ChlorineContaining Atmosphere,” Surf. Coat. Technol., Vol.161,pp 275-285, 2002.

[14] An Introduction to Thermal Spray, Issue 6, 2015.

[15] Metco,S.www.sulzermetco.com/de/desktopdefault.aspx/tabid-008/3390_read-5302. 2008.

[16] K.V. Rao, "Properties and characterisation of coatings made using jet kote thermal spray technique," Proceedings of the 11th International Thermal Spray Conference, Montreal, Canada, pp. 873-882, 1986.

[17] D.C. Crawmer, J.D. Krebsback, and W.L. Riggs, "Coating development of HVOF process using design of experiments," Proceedings of the 13th International Thermal Spraying Conference, Florida, pp. 127-136, 1992.

[18] Jarosinski, W.J., Gruninger, M.F. and Londry, C.H., "Characterisation of tungsten carbide cobalt powder and HVOF coatings," Proceedings of the Fifth National Thermal Spray Conference, California, pp. 153-158, 1993.

[19] S. Ahmaniemi, P. Vuoristo and T. Mäntylä, "Mechanical \& Elastic properties of Modified thick Thermal Barrier Coatings", Materials Science and Engineering A, Vol. 366 (1), pp.175-182, 5 February 2004.

[20] L.N. Moskowitz, "Application of HVOF Thermal Spraying to Solve Corrosion Problems in the Petroleum Industry," Proceedings of 13th International Thermal Spray Conference, Florida, USA. pp. 611-618, August 1992.

[21] J.C. Tan, L. Looney, and M.S.J.Hashmi, “Component repair using HVOF thermal spraying,” JMPT, Vol.92, pp.203-208, 1999. 
[22] J. Stokes, and L. Looney, "HVOF system definition to maximize the thickness of formed components," Surface coating Technology, Vol.148, pp.18-24, 2001.

[23] T.S. Sidhu, S. Prakash, and R.D. Agrawal, Studies on the properties of highvelocity oxy-fuel thermal spray coatings for higher temperature applications. Materials Science, Vol. 41(6), pp. 805-823, 2005.

[24] T.S. Sidhu, S. Prakash, R.D. Agrawal, R.D., "Hot Corrosion Behaviour of HVOF Sprayed NiCrBSi Coating on Ni and Fe Based Super alloy in $\mathrm{Na}_{2} \mathrm{SO}_{4}-60 \% \mathrm{~V}_{2} \mathrm{O}_{5}$ Environment, Acta Materialia, Vol.54, pp.773-784, 2006.

[25] H.S. Sidhu, B.S. Sidhu, and S. Prakash, "Hot Corrosion Behavior of HVOF sprayed Coatings on ASTM SA213-T11 Steel,'Thermal Spray Technology, Vol.6(3),pp.349- 354,2006.

[26] T.S. Sidhu, S. Prakash, and R.D. Agrawal, "A Comparative Study of Hot Corrosion Resistance of HVOF Sprayed NiCrBSi and Stellite-6 Coated Ni Based Super alloy at $900^{\circ}$ C," Material Sc. and Engg., pp. 445-446,2006.

[27] G. Kaushal, H. Singh, and S. Prakash, High Temperature Corrosion Behaviour of HVOF-sprayed Ni-20Cr Coating on Boiler Steel in Molten Salt Environment at $900^{\circ}$ C, Int. J. Surface Science and Engineering, Vol.5, pp.415-433,2012.

[28] S. Singh, K. Goyal, and R. Goyal, "Performance of $\mathrm{Cr}_{3} \mathrm{C}_{2}-25(\mathrm{Ni}-20 \mathrm{Cr})$ and Ni-20Cr Coatings on T91 Boiler Tube Steel in Simulated Boiler Environment at $900^{\circ} \mathrm{C}, "$ Chemical and Materials Engineering, Vol. 4(4), pp.57-64, 2016.

[29] T.S. Sidhu, S. Prakash, and R.D. Agrawal, "Hot Corrosion Resistance of High-Velocity Oxy-fuel Sprayed Coatings on a Nickel-Base Super alloy in Molten Salt Environment,” Thermal Spray Technology, Vol.15(3), pp.387-399,2006.

[30] T.S. Sidhu, S. Prakash, and R.D. Agrawal, "Characterization of HOVF Sprayed NiCrBSi Coating Ni- and Fe Based Super alloy in Molten Salt Environment,” Thin Solid Film,Vol. 515, pp.95-105, 2006.

[31] H.S. Sidhu, B.S. Sidhu, and S. Prakash, Evaluation of Hot Corrosion Behavior of LPG assisted HVOF NiCr Wire Sprayed Boiler Tube Steel in Molten Salt Environment, ISIJ International, Vol.4, pp.1067-1074,2006.

[32] T. S. Sidhu, S. Parkash, R. D. Aggarwal and R. Bhagat, "Erosion-corrosion behaviour of Ni-Based superalloy Superni-75 in the real service environment of the boiler", Sadhana Vol. 34, pp.299-307, April 2009.

[33] M. Kaur, H. Singh and S. Parkash, "High Temperature Corrosion Studies of HVOF Sprayed Cr3C2-NiCr Coating on SAE-347H Boiler Steel”, Journal of thermal spray coating, vo.18(4), pp.619-628, December 2009.

[34] R. Bhatia, H. Singh, and B. S. Sidhu, "Hot Corrosion Studies of HVOF-Sprayed Coating on T-91 Boiler Tube Steel at Different Operating Temperatures", Journal of materials engineering and performance, vol. 23, pp. 493-505, 2014.

[35] S. Singh, K. Goyal and R. Goyal, "Performance of Cr3C2-25 (Ni-20Cr) and Ni-20Cr coatings on T-91 boiler tube steel in simulated boiler environment at $900^{\circ} \mathrm{C}$ ", Chemical and material engineering, Vol. 4, pp.57-64, 2016.

[36] S. S. Chatha, H. S. Sidhu and B. S. Sidhu, "Performance of $75 \mathrm{Cr} 3 \mathrm{C} 2-25 \mathrm{NiCr}$ coating Produced by HVOF process in coal fired thermal power plant", Advanced material research, vol.1137, pp.88-100, 2016. 